\title{
Expelled: Humans in Capitalism's Deepening Crisis
}

$\underline{\text { Saskia Sassen }}$

Columbia University

sjs2@columbia.edu

As the Cold War was winding down, a new struggle began. Following a period of diverse versions of Keynesian-led relative redistribution in developed market economies, the United States became the point actor for a radical reshuffling of capitalism. Key to this reshuffling was expulsion - of people, places, and traditional economies (see Sassen 2014). While this is a socioeconomic condition it is a critical, but invisible, element of the current political crisis. Measuring economic growth to understand whether government policies are working, or measuring political participation in terms of voting, excludes growing portions of our political economy - people, specific types of firms and economic circuits, and spaces. The Keynesian period was one of mass production and mass construction of suburban space: this brought with it an economic logic that valued people as workers and consumers, though not necessarily as human beings. The logic guiding the current phase of advanced capitalism does not value people as workers or as (mass) consumers. Thus, in the last two decades there has been a sharp growth in the numbers of people that have been "expelled" from the economy in much of the world. The active expanding of a middle class in that earlier period has been replaced by the impoverishment and shrinking of the middle class.

This holds in extreme form for particular countries, notably the United States and several African countries that once had strong manufacturing economies but now have become mainly extractive economies. It is the manufacturing- and construction-driven economies of China, and to a lesser extent India, that today are actively generating expanding middle classes. But one question is whether these new logics of expulsion I examine in this essay will eventually also set in there, not through some process of evolution that will repeat the West's trajectory, but because of a larger global economic logic that emerged in the 1980s and might envelop countries such as China and India as well. One way of putting it is that the latter will not simply replicate the strong economic trajectories of Japan, South Korea, and Taiwan, with widely distributed economic and social benefits. The logics of expulsion that mark the current post-1980s period will counter such distributive potentials.

I use the term "expelled" to describe a diversity of conditions. They include the growing numbers of the abjectly poor, of the displaced in poor countries who are warehoused in formal and informal refugee camps, of the minoritized and persecuted in rich countries who are warehoused in prisons, of workers whose bodies are destroyed on the job and rendered useless at far too young an age, of able-bodied "surplus populations" warehoused in ghettoes and slums. My argument is that this massive expulsion is actually signaling a deeper systemic transformation, one documented in bits and pieces in multiple specialized studies but not quite narrated as an overarching dynamic that is taking us into a new phase of global capitalism. It has also generated an emergent type of politics, marked by its use of the street (Sassen 2011). 
Today, after twenty years of a particular type of advanced capitalism, we confront a human and economic landscape marked by dualizing dynamics. On the one hand: the familiar reconditioning of terrain in the direction of growing organizational and technological complexity, epitomized by the state of the art space of global cities in the North and the South. On the other hand: a mix of conditions often coded with the seemingly neutral term of "a growing surplus population." A key underlying condition of this "surplus" is the growing expanse of territory that is devastated - by poverty and disease, by various kinds of armed conflict, and by governments rendered dysfunctional by acute corruption and a crippling international debt-regime, all leading to an extreme inability for people to meet their basic needs. To this we should add the sharp increase in land acquisition by foreign firms and foreign government agencies, which is creating additional mass displacements of whole villages and smallholder agriculture.

It is this second emerging condition that concerns me here. It goes against the familiar notion that our modernity is marked by an irresistible growth in organizational and technological complexity. In vast stretches of our very modern world, we see shifts from the complex to the elementary: from the complex encasing of land that is the doctrine of "national sovereign territory," to land in weakened nation-states becoming a commodity to be sold on the global market. And from the complexity of people as citizens, to surplus people - warehoused, displaced, trafficked, reduced to mere laboring bodies and body-organs. ${ }^{1}$

\section{Expanding the Operational Space of Advanced Capitalism}

The geographic expansion and systemic deepening of capitalist relations of production over the last 20 years have led to a brutal sorting of winners and losers. The development of capitalism has since its origins been marked by violence, destruction, and appropriation, but also by the making of the regulatory state, a victory for the struggling working classes, and by the expansion of vast middle classes. Much attention has gone to the destruction of pre-capitalist economies via their incorporation into capitalist relations of production. The post-1980s period makes visible another variant of this appropriation via incorporation - the appropriation of traditional capitalisms to further the deepening of advanced capitalism. I use this term to capture a phase dominated by a financial logic. Built into this proposition is the fact of diverse phases of capitalist development and hence the possibility that in today's global phase the extension of capitalist relations has its own distinct mechanisms and that these need to be distinguished from older national and imperial phases.

Elsewhere (Sassen 2008a: ch. 1, 8,9) I develop a theory of change which has as one core dynamic the fact that condition $\mathrm{x}$ or capability $\mathrm{y}$ can shift organizing logics and thereby actually change valence even if it may look the same. Thus, for instance, the massive expulsion of people alluded to briefly above is not necessarily simply more of the same - more poor, more displaced, more downward mobility. It may be part of a new organizing logic that alters the valence and systemic character of poverty and downward mobility. Thus I find that the organizing logic of this post-Keynesian period is now making legible its shape. One extreme component of this logic diverges sharply from the earlier systemic 'valuing' of people as workers and consumers. To put it dramatically, it is the expulsion of people and the destruction of traditional capitalisms to feed

\footnotetext{
${ }^{1}$ Elsewhere I examine a critical component of these shifts: how much of the sharp rise in complex systems and instruments winds up producing elementary brutalities (cf. Sassen 2014: op cit in fn1).
} 
the needs of high finance and global capitalist production. For instance, what are easily seen as traditional or familiar logics of resource extraction to meet ongoing domestic needs might also be novel ways of preparing the ground for the systemic deepening of advanced capitalism.

One of these instances is the structural adjustment project implemented by global regulatory institutions, notably the IMF, World Bank, and WTO, beginning in the 1980s and escalating in the 1990s. My argument here is that beyond the much noted extraction of billions of dollars from global South countries in the form of debt servicing, systemic conditioning took place; debt servicing was the instrument for this disciplining. The second instance is the subprime mortgage crisis that began in the early 2000s and exploded in 2007: 13 million foreclosure notices and 9 million evicted families. Most of the attention has gone, and rightly so, to the massive losses for the individuals and families who were sold these mortgages, losses that will continue through 2014. In this case my argument is, again, that beyond the logics of extraction in the form of mortgage payments and mortgage agents' fees, here too we can detect a more foundational emergent dynamic: the use of a contract on a material asset (the mortgage) as one ingredient for making a complex investment instrument for high finance.

Central to my analysis is that inside capitalism itself we can characterize the relation of advanced to traditional capitalism as one marked by predatory dynamics rather than merely evolution, development, or progress. ${ }^{2}$ At its most extreme this can mean immiseration and exclusion of growing numbers of people who cease being of value as workers and consumers. But it also means that traditional petty bourgeoisies and traditional national bourgeoisies cease being of value. I see the latter as part of the current systemic deepening of capitalist relations. One brutal way of putting it is to say that the natural resources of much of Africa and good parts of Latin America count more than the people on those lands count as consumers and as workers. This is part of the systemic deepening of advanced capitalist relations of production. We have left behind the varieties of Keynesian periods that thrived on the accelerated expansion of prosperous working and middle classes - though not in today's emergent economies, especially in Asia. Keynesianism's valuing of people as workers and consumers was critical for the deepening of capitalism.

\section{The Expulsion of People and the Incorporation of Terrain}

Notwithstanding their enormous differences, I would argue that the expulsions briefly described here are systemic equivalents - and represent only a few of a broad range of such equivalents. Also, there is a considerable global replication potential of some of these. This is the case for the financial innovation that destroyed many million households in the United States, therewith devastating whole neighborhoods. Thus countries such as Hungary, Spain, and Latvia are experiencing sharp rises in foreclosures over the last few years. And it is the case for the debt and debt servicing regime imposed on global South countries and its prioritizing over all other state expenditures; the case of Greece and several other global North countries makes this clear.

Both cases can be seen as part of a much larger process of financial deepening, one of today's major dynamics characterizing advanced capitalist economies. Financial deepening requires specific mechanisms, which can be extremely complex, as in the case of the type of sub-

\footnotetext{
${ }^{2}$ Elsewhere I examine to what extent Marx's analysis of primitive accumulation to explain the relationship between capitalism and pre-capitalist economies might illuminate this relationship between traditional and the new types of advanced capitalism (see Sassen 2010).
} 
prime mortgage examined here, or they can be quite elementary, as in the debt servicing regime that took off in the 1990 s in the global South and has now spread to the global North (See, e.g., Panitch 2013).

One way of thinking of this systemic deepening is as the expansion of the operational space for advanced capitalism; it expels people both in the global South and in the North even as it incorporates spaces. The devastated economies of the global South, subjected to a full decade or two of debt servicing, are now being incorporated into the circuits of advanced capitalism through the accelerated acquisition of millions of hectares of land by foreign investors - to grow food and extract water and minerals, all for the capital investing countries.

This also holds for such a radically different instance as the sub-prime mortgage crisis, a largely global North dynamic. I see the sub-prime mortgage as extending the domain for high finance but in a way that delinks the financial circuit from the actual material entity that is the house, and hence from the neighborhood, and from the people who got the mortgage. All of these materialities are excluded from this type of articulation with high-finance - which means that the devastated neighborhoods are expelled from what are, strictly speaking, also traditional circuits of capital. It is akin to wanting only the horns of the rhinoceros, and throwing away the rest of the animal, devaluing it, no matter its multiple utilities. Or using the human body to harvest some organs, and seeing no value in all the other organs, let alone the full human being it can all be discarded. But unlike the clear realignments we see in vast stretches of the global South, it is not clear how these devastated urban spaces in the global North will be incorporated into the circuits of advanced capitalism.

This systemic shift signals that the sharp increase in displaced peoples, in poverty, in deaths from curable illnesses, are part of this new phase. Key features of primitive accumulation are at work in the making of these increases. But to see this role of primitive accumulation in our current advanced capitalism dominated by high finance we have to go beyond logics of extraction. We need to recognize the fact of systemic transformation. One of these systemchanging practices and projects is the expulsion of people: growing numbers matter less as workers and consumers than they did in much of the $20^{\text {th }}$ century, which helps account for the pattern Robinson describes as the rise of social control states around the world (2013).

\section{References}

Panith, Leo. 2013. "Crisis of What?" Journal of World-Systems Research 19(2): 181-185.

Robinson, William I. 2013. "Policing the Global Crisis." Journal of World-Systems Research 19(2): 193-197.

Sassen, Saskia. 2008. Territory, Authority, Rights: From Medieval to Global Assemblages. Princeton, NJ: Princeton University Press.

-----. 2010. "A Savage Sorting of Winners and Losers: Contemporary Versions of Primitive Accumulation." Globalizations 7(1-2): 23-50.

-----. 2011. "The Global Street: Making the Political." Globalizations 8(5): 565-571.

-----. 2014 (Forthcoming, January). Expulsions: Brutality and Complexity in the Global Economy. Cambridge, MA: Harvard University Press. 